\title{
New records of the Alcathoe bat, Myotis alcathoe (Vespertilionidae) for Italy
}

\author{
Pier Paolo De Pasquale ${ }^{1 *}$, Andrea Galimberti ${ }^{2}$
}

${ }^{1}$ Wildlife consulting, Via G. Saragat 24, 70027 Palo del Colle (Bari), Italy

${ }^{1}$ Italian Chiroptera Research Group, Università degli Studi dell'Insubria, via Dunant,3 Varese

2 ZooPlantLab, Università degli Studi di Milano-Bicocca,

Dipartimento di Biotecnologie e Bioscienze, P.za della Scienza 2, 20126 (Milano), Italy

* Corresponding author e-mail: wildlifeconsulting.italy@gmail.com

DOI: http://dx.doi.org/10.14709/BarbJ.7.1.2014.01

Spanish title: Nuevas citas de murciélago ratonero bigotudo pequeño, Myotis alcathoe (Vespertilionidae) en Italia

\begin{abstract}
The Alcathoe bat (Myotis alcathoe) is a recently described cryptic species; in Europe its distribution range is poorly known. In Italy this species has been recorded in a small number of locations in Abruzzo (central Italy) and Campania (southern Italy). Our report refers to three bats captured in a mountainous area dominated by forest habitats in the Appennino Lucano Val d'Agri Lagonegrese National Park (Basilicata region). The identification of bats captured was confirmed by molecular analysis using the technique of DNA barcoding. In this paper we present new recordings that highlight the presence of the species in other regions of southern Italy and that help define its distributional status in Europe.
\end{abstract}

Key words: Myotis alcathoe, cryptic species, DNA barcoding, coxI.

The presence of cryptic species seem to be widespread among vespertilionid bats and especially in the genus Myotis (Jones and Barlow 2004).

Myotis alcathoe is a recently described cryptic species (von Helversen et al. 2001) belonging to the group mystacinus. This small bat is difficult to identify only through morphological analysis.

Although the species can be identified using both morphological characters and genetic markers, only the later provide full confidence about it (Niermann et al. 2007). In Europe population size and trends of $M$. alcathoe are poorly known.

In Italy the species was recorded for five localities in Abruzzo (central Italy) and Campania (southern Italy). All bats were captured in beech forests (Tereba et al. 2008, Galimberti et al. 2012).
Our records were collected as part of a survey of bats covering the entire territory of the Appennino Lucano Val d'Agri Lagonegrese National Park (south-west of the Basilicata region). We made two capture sessions on 3 and 6 August, 2012 near two small mountain lakes at 1167 and $1304 \mathrm{~m}$ a.s.1., respectively. Small lakes are part of a forest reserve dominated by beech (Fagus sylvatica) associated with other tree species, such as Lobel maple (Acer lobelii), sycamore (Acer pseudoplatanus) and Small-leaved Lime (Tilia cordata), fig. 1.

Bats were captured with $2.5 \times 12 \mathrm{~m}$ mist-nets (50 denier, $38 \mathrm{~mm}$ mesh) placed on commuting routes and near small lakes used by bats for drinking and foraging.

The nets were deployed half an hour after sunset and kept in place for 4 hours. Forearm length and body mass of each bat trapped were measured using a digital callipers $( \pm 0.1$ $\mathrm{mm})$ and a pesola digital scale $( \pm 0.1 \mathrm{~g})$. Wings were trans- 


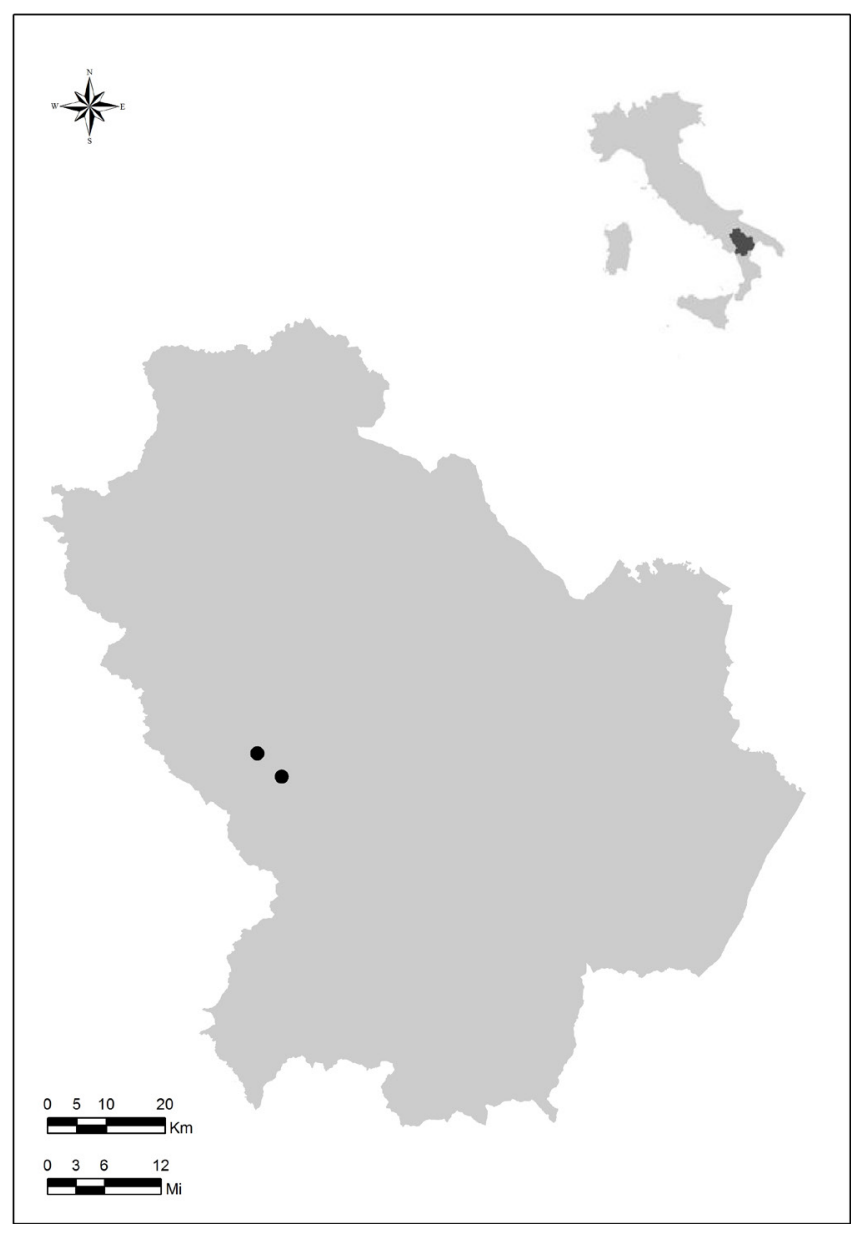

Fig. 1 - Records of Myotis alcathoe.

illuminated to distinguish juveniles from adults (Antony 1988).

Bats captured were subjected to a skin biopsy using a sterile punch of a $3 \mathrm{~mm}$ diameter from the tail membrane (uropatagium) (Worthington Wilmer and Barratt 1996).

Samples were stored in sterile tubes containing 95\% ethanol for subsequent molecular analysis.

Total genomic DNA was extracted from tissue samples using 5 PRIME, ArchivePure DNA Purification Kit. A fragment of ca. $650 \mathrm{bp}$ of the mitochondrial subunit 1 of cytochrome c oxidase, suitable for echolocating bats identification (Galimberti et al. 2012), was amplified for the three sampled bats using the primers VF1d 5'TTCTCAACCAACCACAARGAYATYGG-3' and VR1d 5'-TAGACTTCTGGGTGGCCRAARAAYCA-3' from Ivanova et al. (2007).

PCR reactions were performed in $20 \mu$ l reactions using ca. $1 \mathrm{ng}$ of genomic DNA, $0.2 \mu \mathrm{l}$ of VF1d $(0.2 \mathrm{mM}), 0.2 \mu \mathrm{l}$ of VR1d $(0.2 \mathrm{mM}), 2 \mu \mathrm{l}$ of total dNTPs $(0.2 \mathrm{mM}), 0.1 \mu \mathrm{l}$ of $(0.5 \mathrm{U})$ of MasterTaq Eppendorf $\AA, 2 \mu \mathrm{l} 1 \mathrm{x}$ Buffer including $\mathrm{MgCl} 2$ at $1.5 \mathrm{mM}$ and $14.5 \mu \mathrm{l}$ of water. PCR conditions were: $1 \mathrm{~min}$ at $94^{\circ} \mathrm{C}$, followed by 5 cycles of $30 \mathrm{~s}$ at $94^{\circ} \mathrm{C}, 40 \mathrm{~s}$ at 50 ${ }^{\circ} \mathrm{C}$, and $1 \mathrm{~min}$ at $72^{\circ} \mathrm{C}$, followed by 35 cycles of $30 \mathrm{~s}$ at $94^{\circ} \mathrm{C}$, $40 \mathrm{~s}$ at $55^{\circ} \mathrm{C}$, and $1 \mathrm{~min}$ at $72^{\circ} \mathrm{C}$, and ending with $10 \mathrm{~min}$ at $72^{\circ} \mathrm{C}$ The light strands were sequenced using an $\mathrm{ABI} 3730 \mathrm{XL}$ by Macrogen Inc. Chromatographs were checked by eye and sequences were edited, when necessary, using the BioEdit sequence alignment editor (version 7.0.5.3; Hall 1999).
To assess species attribution each sequence was compared using the BLAST algorithm in GenBank, where sequences belonging to almost all the Italian echolocating bats species are available thanks to a previous study (Galimberti et al. 2012). All sequences have been deposited in GenBank (HG325822-23-24).

We caught three lactating females $(\mathrm{FAL}=33.6,32.9$ and $33.0 \mathrm{~mm}$ respectively; weight $=4.7,4.9$ and 4.0 ) from the "M. mystacinus group", two in Marsico Nuovo (altitude 1167 $\mathrm{m}$ a.s.l) and one in Calvello (altitude $1304 \mathrm{~m}$ a.s.l.). All there caught in beech forest sites.

Molecular analysis of these samples allowed the taxonomic identification of the three bats as belonging to the species $M$. alcathoe. The high similarity matches with reference deposited sequences excluded the misidentification with other congenerics.

In central and eastern Europe, M. alcathoe seems to prefer deciduous forests with old trees and streams (Niermann et al. 2007; Řehák et al. 2008; Lučan et al. 2009; Bashta et al. 2011). Our data adds further records for the presence of M. alcathoe in beech forests of southern Italy (Tereba et al. 2008).

\section{ACKNOWLEDGEMENTS}

Fieldwork was conducted under licence from the Italian Environment Ministry (prot. PNM-2012-0000644). We are indebted with FEM2 Ambiente srl of the Università of Milano-Bicocca for performing the molecular taxonomic identification. The authors are grateful also to Danilo Russo (University of Naples) for his valuable advice and Antonio Conte for logistic support during fieldwork.

This work was funded by the Appennino Lucano National Park Authority.

\section{REFERENCES}

Agnelli, P., Martinoli, A., Patriarca, E., Russo D., Scaravelli, D. \& Genovesi, P. (Eds.), 2004. Guidelines for bat monitoring: methods for the study and conservation of bats in Italy. Quad. Cons. Natura, 19, MATTM, Italian Wildlife Institute, Italian Chiroptera Research Group.

Anthony, E. L. P. 1988. Age determination in bats. Pp. 47-58 in Ecological and behavioral methods for the study of bats, ed. T.H. Kunz, Smithsonian Institution Press, Washington, DC.

Bastha, A. T., Piskorski, M., Mislajek, R. W., Tereba, A., Korneliusz, K. \& Sachanowicz, K. 2011. Myotis alcathoe in Poland and Ucraine: new data on its status and habitat in central Europe. Folia Zool. - 60 (1): $1-4$.

Dietz, C. \& Von Helversen, O. 2004. Illustrated identification key to the bats of Europe. Electronic publication, version 1.0, Tübingen. 
Galimberti,A.,Spada,M.,Russo,D.,Mucedda,M.,Agnelli, P., Crottini, A., Ferri, E., Martinoli,A. \& Casiraghi, M. 2012. Integrated Operationali Taxonomic Units (IOTUs) in Echolocating Bats: A Bridge Between Molecular and Traditional Taxonomy. PLo S ONE 7(6): e401 22. doi:10.1 371/journal.p one.0040122. DOI: http://dx.doi.org/10.1371/journal.pone.0040122

HaLl, T. A., 1999. BioEdit: a user-friendly biological sequence alignment editor and analysis program for Windows 95/98/NT. Nucleic Acids Symposium, 41, 95-98.

Ivanova, N. V., Zemlak, T. S., Hanner, R. H. \& Hebert, P. D. N., 2007. Universal primer cocktails for fish DNA barcoding. Mol Ecol Notes 7: 544-548. DOI: http:// dx.doi.org/10.1111/j.1471-8286.2007.01748.x

Jones, G. \& Barlow, K E., 2004. Cryptic Species of Echolocating Bats, Pp. 345-349 in: Echolocation in Bats and Dolphin, ed. THOMAS J.A., MOSS C.F., VATER M., the University of Chicago Press.

LuČan, R. K., Andreas, M., Benda, P., BartoničKa, T., Brezinova, T., Hoffmannová, A., Hulová, Š., Hulva, P., NeCKÁŘoví, J., ReIter, A., SvaČInA, T., Š́́leK, M. \& HorÁČEK, I. 2009. Alcathoe bat (Myotis alcathoe) in the Czech Republic: distributional status, roosting and feeding ecology. Acta Chiropterol. 11: 61-69. DOI: http://dx.doi.org/10.3161/150811009X465695

NiERMANn,I.,BiEdERMANN,M.,BogdanOWICZ,W.,BrinkMANN, R., LeBris, Y., Ciechanowski, M., Dietz, C., Dietz, I., Estók,P., VonHelversen,O.,LeHouédec,A.,Paksuz,
S., Petrov, B., Öskan, B., Piksa, K., Rachwald, A., Roué, S.Y., Sachanowicz, K., Schorcht, W., Tereba, A. \& MAYER, F. 2007. Biogeography of the recently described Myotis alcathoe von Helversen \& Heller, 2001. Acta Chiropterol. 9 (2): 361-378.

ŘEhák, Z., BARTONiČKA, T., BRyja, J. \& GAisler, J. 2008. New records of the Alcathoe bat, Myotis alcathoe in Moravia (Czech Republic). Folia Zool. 57: 465-469.

Tereba, A., Russo, D., Cistrone, L. \& Bogdanowicz, W. 2009. Cryptic diversity: first record of Myotis alcathoe (Vespertilionidae) for Italy. Acts of the 2nd Italian Bat Congress, pp.157: 85-88.

Von Helversen, O., Heller, K.-G., Mayer, F., Nemeth, A., VolLETH,M.\&GOMBKÖTÖ,P.2001.Crypticmammalian species: a new species of whiskered bat (Myotis alcathoe n.sp.) in Europe. Naturwissenschaften 88: 217-223.

WORTHINGTON-WiLMER, J. \& BARRATt, E. M. 1996.Anonlethal method of tissue sampling for genetic studies of chiropterans. Bat Research News, 37: 1-3. 